\title{
Type I IFN and TNFa cross-regulation in immune-mediated inflammatory disease: basic concepts and clinical relevance
}

\author{
Tineke Cantaert, Dominique Baeten, Paul P Tak* and Lisa GM van Baarsen
}

\begin{abstract}
A cross-regulation between type I IFN and TNFa has been proposed recently, where both cytokines are hypothesized to counteract each other. According to this model, different autoimmune diseases can be viewed as disequilibrium between both cytokines. As this model may have important clinical implications, the present review summarizes and discusses the currently available clinical evidence arguing for or against the proposed cross-regulation between TNFa and type I IFN. In addition, we review how this cross-regulation works at the cellular and molecular levels. Finally, we discuss the clinical relevance of this proposed cross-regulation for biological therapies such as type I IFN or anti-TNFa treatment.
\end{abstract}

\section{Type I IFN and TNFa: cytokines with pleiotropic functions}

The family of type I IFN consists of multiple subtypes of IFN $\alpha$, a single IFN $\beta$ and some less characterized family members, such as IFN $\varepsilon$, IFNK and IFN $\omega$. The difference in biological function between the multiple subtypes of type I IFN is unclear, especially since the induced genes downstream of the different types of IFN (the IFN response program) are highly similar between, for example, IFN $\alpha$ and IFN $\beta$. In peripheral blood, plasmacytoid dendritic cells (pDC) are the main producers of type I IFN. All nucleated cells, however, can produce type I IFN upon activation by, for example, viral infections that trigger cytoplasmic nucleic acid sensors such as TLR-7 and MDA-5.

Binding of type I IFNs to their cognate receptor (a heterodimer of IFNAR1 and IFNAR2) leads to the

*Correspondence: P.P.Tak@amc.uva.nl

Academic Medical Center/University of Amsterdam, Meibergdreef 9,

1105 AZ Amsterdam, the Netherlands phosphorylation of signal transducers and activators of transcription (STATs) and transcription of IFN response genes. This results in resistance to viral replication, enhanced MHC class I expression and differentiation of monocytes, all of which contribute to clear infection. Besides an essential role in the host antiviral state, type I IFN has immunoregulatory functions by affecting cell proliferation and differentiation and by inducing antiinflammatory responses. Considering these important functions of type I IFN in normal homeostasis as well as host response, an aberrant function in type I IFN immunity may contribute to autoimmunity and chronic inflammation. This is illustrated by the observation that melanoma patients treated with IFN $\alpha 2 \beta$ developed clinical and serological signs of autoimmunity [1] and that patients with a trisomy of chromosome 9, which contains the type I IFN genes, develop high IFN levels and lupus-like disease [2].

TNF $\alpha$ is a pivotal pro-inflammatory cytokine produced by macrophages, activated $\mathrm{T}$ cells, natural killer cells and mast cells. Also non-immune, stromal cells are able to produce significant amounts of TNF $\alpha$. TNF $\alpha$ is produced as a $26 \mathrm{kDa}$ transmembrane protein, which can be cleaved by TNF $\alpha$ converting enzyme to form the $17 \mathrm{kDa}$ soluble form. Upon binding to TNFR1 (which is constitutively expressed on most cell types) or TNFR2 (which is expressed on immune cells, endothelial cells and fibroblasts), TNF $\alpha$ activates the mitogen-activated protein kinase and NF-kB signaling pathways [3] - which in turn can lead to an amplification of the proinflammatory response by increased production of chemokines and cytokines, including TNFo itself. Endothelial cells respond to TNF $\alpha$ by expressing adhesion molecules to facilitate trafficking of immune cells to the inflamed tissue. Macrophages and neutrophils are attracted to the site, increase their cytokine production, and enhance phagocytic capacities. Taken together, TNF $\alpha$ initiates and orchestrates different mechanisms that lead to an effective immune response in the case of infection.

Besides its role in host defense, however, TNF $\alpha$ is recognized to play a key role in many immune-mediated inflammatory diseases (IMIDs), such as rheumatoid 
(a)

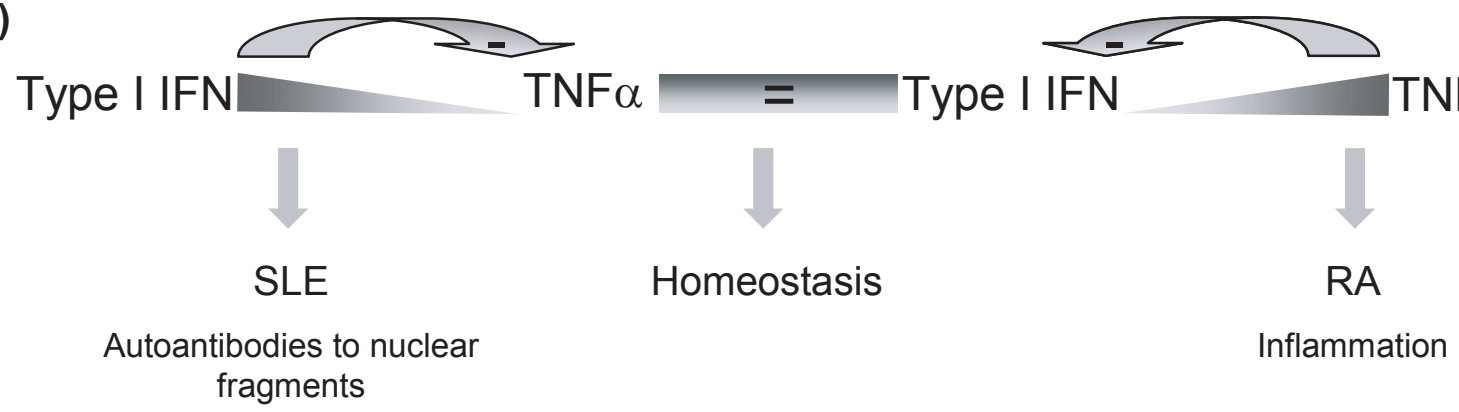

(b)

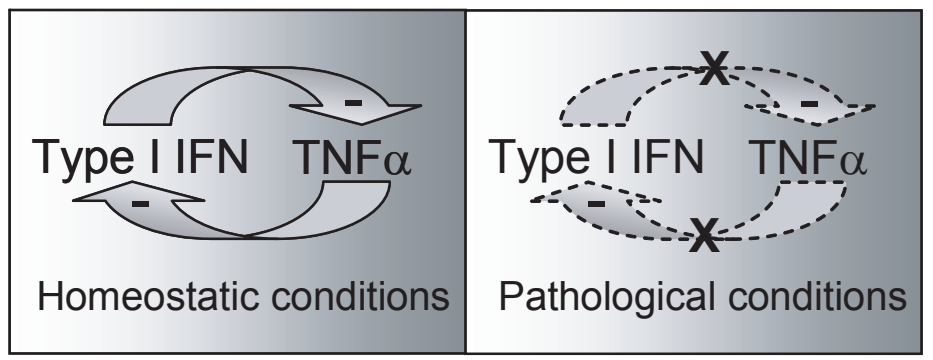

(c)

Type I IFN

TNF $\alpha$

Induction of autoimmunity $\ldots \ldots \ldots \ldots$ Effector phase of disease

Figure 1. Cross-regulation between type I IFN and TNFa. (a) The original hypothesis proposes that both cytokines can be regarded as opposite vectors. Whereas the sum of both vectors normally yields an equilibrium point allowing protective immunity, disturbance of this balance beyond a certain threshold may contribute to a pathological state promoting autoimmunity, allergy, or inflammation. A shift towards the TNFa arm may create a permissive environment for TNF-mediated autoimmunity in rheumatoid arthritis (RA). In contrast, when the type I IFN arm prevails, IFNdriven autoimmunity as observed in systemic lupus erythematosus (SLE) may occur. (b) An alternative hypothesis: in homeostatic conditions, type IFN and TNFa are influencing each other's levels but this balance is lost in a pathological condition. (c) An alternative hypothesis: type I IFN plays an important role in the initiation of autoimmunity, while the role of TNFa increases during the secondary inflammatory phase.

arthritis (RA), spondyloarthritis, psoriasis, and inflammatory bowel disease [4]. Accordingly, anti-TNF $\alpha$ treatment is very effective in these conditions. Interestingly, a recent animal study showed that the primary cell target of TNF in chronic inflammatory joint and intestinal diseases is mesenchymal cells [5], a cell type that can produce large amounts of type I IFN.

\section{Cross-regulation of TNFa and type I IFN: the hypothesis}

The relative contribution of TNF $\alpha$ and type I IFN to different types of autoimmunity and inflammatory disease is not well understood. An even more complex and intriguing picture emerged from the recently proposed hypothesis of an intimate interplay between both pleiotropic cytokines [6,7]. This hypothesis proposes that, similarly to Th1 and Th2 cytokines in T-cell biology, both cytokines can be regarded as opposite vectors in many innate immune responses. If both vectors are in balance, the sum normally yields an equilibrium point allowing protective immunity. Disturbance of this balance beyond a certain threshold may contribute to pathological conditions such as autoimmunity and inflammation (Figure 1a). A shift towards the TNF $\alpha$ arm may create a permissive environment for TNF-mediated autoimmunity such as RA. In contrast, when the type I IFN arm prevails, IFN-driven autoimmunity such as systemic lupus erythematosus (SLE) may occur.

This concept was first formulated by Ivashkiv in 2003 based on the clinical observation that a fraction of RA patients treated with anti-TNF $\alpha$ therapy develop antinuclear antibodies and even sometimes lupus-like syndromes that reverse with the cessation of the therapy [7]. Banchereau and colleagues further established this hypothesis after the observation that five juvenile chronic arthritis patients treated with anti-TNF $\alpha$ therapy showed 
overexpression of IFN $\alpha$-regulated genes in their peripheral blood mononuclear cell (PBMC) compartment compared with untreated control patients [6,8]. In addition, they showed that IFN $\alpha$ production by virally stimulated pDC is inhibited by TNF $\alpha$ through induction of maturation [8]. As this conceptual model may have important clinical implications for treatment with TNF $\alpha$ blockers or with type I IFN, the present review summarizes and discusses the currently available clinical evidence for the proposed cross-regulation between TNF $\alpha$ and type I IFN at the cellular level as well as in vivo in experimental models and in IMID patients. A summary of all studies cited is presented in Tables 1 and 2 .

\section{Cross-regulation of TNFa and type I IFN at the cellular level}

At the cellular level, the hypothesis of cross-regulation between TNF $\alpha$ and type I IFN is based on the observation that TNF $\alpha$ inhibits the generation of $\mathrm{pDC}$ as well as the secretion of type I IFN by immature pDC upon viral triggering [8]. Incubation of influenza-virus activated pDC with TNF $\alpha$ inhibited the IFN $\alpha$ production by $40 \%$, which was due to maturation of the $\mathrm{pDC}$ by TNF $\alpha$ rather than a direct inhibition or cross-regulation. In vitro culture of healthy PBMCs with the soluble TNFa receptor etanercept resulted in a dose-dependent increase in the expression of IFN $\alpha$ and IFN $\alpha$-inducible genes [9]. These studies specifically focused on IFN $\alpha$ and not on IFN $\beta$, but similar genes are induced by IFN $\beta$. In contrast with these findings in PBMCs, studies on human fibroblasts indicated that stimulation with TNF $\alpha$ induced an approximately 16 -fold increase in the steady-state level of IFN $\beta$ mRNA [10]. Moreover, it has been shown more recently that TNFo induces a type I IFN response program in macrophages through IFN regulatory factor-1 activation, leading to an IFN $\beta$-mediated autocrine loop [11]. The TNF $\alpha$ canonical pathway and the IFN $\beta$ pathway may thereby synergize in the expression of downstream response genes. Taken together, these data suggest that the suppressive effect versus stimulating effect of TNF $\alpha$ on the synthesis of type I IFN is not universal but, rather, is cell-type dependent.

The opposite question related to the presumed crossregulation is whether type I IFN suppresses TNF $\alpha$ production. Indeed, several studies have shown suppressive effects of type I IFN. Stimulation of peripheral blood cells with IFN $\beta$ decreases the production of TNFa $[12,13]$. In addition, IFN $\beta$ augmented dexamethasonemediated suppression of TNF $\alpha$ in a human monocytic cell line [14]. A study on human macrophages indicated that IFN $\alpha$ can suppress TNF $\alpha$ production after immune complex, Fc receptor or Toll-like receptor stimulation by induction and activation of Axl, a receptor tyrosine kinase that induces the expression of a transcriptional repressor of the TNF $\alpha$ promoter [15]. Moreover, IFN $\beta$ can induce the expression of tristetraprolin, an RNAbinding protein that destabilized the mRNA of proinflammatory cytokines including TNF $\alpha$ [16]. Accordingly, IFN-induced tristetraprolin limits lipopolysaccharide (LPS)-induced expression of several proinflammatory cytokines, including TNF $\alpha$, by macrophages.

Of interest, the inhibitory effect of IFN $\beta$ on TNF $\alpha$ production by human monocytes was shown to be stimulus dependent. IFN $\beta$ diminishes TNF $\alpha$ production in $\mathrm{T}$-cell contact-activated monocytes, while IFN $\beta$ enhances TNF $\alpha$ production in LPS-activated monocytes [17]. Another study showed that direct stimulation of murine macrophages with IFN $\beta$ does not suppress TNF $\alpha$ but, on the contrary, induces a fourfold upregulation of TNF $\alpha$ mRNA expression [18]. Whether the same holds true for IFNa awaits further investigation. Besides these direct effects, low constitutive expression of type I IFN in many cell types contributes to boost the responsiveness towards other cytokines. This phenomenon - called cross-priming implicates that previous exposure to low doses of the pleiotropic type I IFN enhances subsequent response to proinflammatory cytokines such as TNF $\alpha$ [19]. Taken together, these cellular studies yield conflicting results going from cross-priming to cross-regulation of TNF $\alpha$ production by type I IFN. This may be partially due to differences in experimental settings mimicking homeostasis versus inflammatory conditions.

\section{Counterbalance of TNFa and type I IFN in experimental models of inflammation and autoimmunity}

The cellular studies indicated that the proposed crossregulation of type I IFN and TNF $\alpha$ may depend on both cell type and inflammatory conditions, thereby emphasizing the need for additional information on this crossregulation in vivo in the context of tissue inflammation and autoimmunity. The NZB/W mouse, a model for SLE, bears a genetic defect in the TNF $\alpha$ gene that leads to reduced levels of TNF $\alpha$ [20]. These mice develop antinuclear antibodies and nephritis. In accordance, treatment of the mice with TNF $\alpha$ resulted in attenuation of the disease.

An IFNa signature has been characterized in the splenic mononuclear cells of pre-autoimmune NZB/W mice that is not observed in BALB/c control mice [21]. Also, whereas IFN $\alpha$ serum levels are undetectable in both $\mathrm{Balb} / \mathrm{c}$ control mice and NZB/W mice under homeostatic conditions, NZB/W mice but not Balb/c control mice produced IFN $\alpha$ after poly I:C stimulation [22]. On the other hand, IFN $\beta$ KO mice, which have an increased susceptibility to experimental autoimmune encephalomyelitis, display extensive microglia activation and TNF $\alpha$ 
Table 1. Complex relation between TNFa and type I IFN in human studies

\begin{tabular}{|c|c|c|c|c|c|}
\hline $\begin{array}{l}\text { Cross- } \\
\text { regulation }\end{array}$ & $\begin{array}{l}\text { Cell } \\
\text { type }\end{array}$ & $\begin{array}{l}\text { Activation } \\
\text { state }\end{array}$ & $\begin{array}{l}\text { Experimental } \\
\text { model }\end{array}$ & Results & Reference \\
\hline \multirow[t]{6}{*}{$\overline{\mathrm{TNF} \downarrow} \Rightarrow \mathrm{IFN} \uparrow$} & PBMCs & $J \mathrm{~A}$ & $\begin{array}{l}\text { Anti-TNFa-treated vs. untreated } \\
\text { patients }\end{array}$ & $\begin{array}{l}\text { Patients treated with anti-TNFa showed higher } \\
\text { IFNa-regulated genes }\end{array}$ & [8] \\
\hline & PBMCs & Healthy & In vitro culture with etanercept & $\begin{array}{l}\text { Dose-dependent increase in transcription of } \\
\text { IFNa inducible genes }\end{array}$ & [9] \\
\hline & Blood & RA & Infliximab-treated RA patients & $\begin{array}{l}\text { Upregulation of type I IFN response genes only in } \\
\text { patients with a poor clinical response }\end{array}$ & [52] \\
\hline & Serum & SpA & $\begin{array}{l}\text { Etanercept-treated SpA patients } \\
\text { (all good clinical response) }\end{array}$ & $\begin{array}{l}\text { Small increase in IFNa activity after } 12 \text { weeks } \\
\text { of treatment }\end{array}$ & [53] \\
\hline & Plasma & SS & $\begin{array}{l}\text { Etanercept-treated SS patients } \\
\text { (poor clinical response) }\end{array}$ & $\begin{array}{l}\text { Increase plasma in IFNa activity after } 12 \text { weeks } \\
\text { of treatment }\end{array}$ & [9] \\
\hline & Plasma & $\begin{array}{l}\text { Inflammatory } \\
\text { myopathy }\end{array}$ & $\begin{array}{l}\text { Infliximab-treated patients } \\
\text { (no clinical response) }\end{array}$ & Increase in serum type I IFN activity & [55] \\
\hline $\mathrm{TNF} \downarrow \Rightarrow \mathrm{IFN} \downarrow$ & Serum & SpA & $\begin{array}{l}\text { Infliximab-treated SpA patients } \\
\text { (all good clinical response) }\end{array}$ & $\begin{array}{l}\text { Slightly decrease in IFNa activity after } 2 \text { weeks } \\
\text { that returns to baseline after } 12 \text { weeks }\end{array}$ & [53] \\
\hline $\mathrm{TNF} \uparrow \Rightarrow \mathrm{IFN} \downarrow$ & $\mathrm{pDC}$ & Influenza virus & $\begin{array}{l}\text { Incubation of virus-activated } \\
\text { pDC with TNFa }\end{array}$ & TNFa inhibited IFNa, probably due to pDC maturation & [8] \\
\hline \multirow[t]{5}{*}{$\mathrm{TNF} \uparrow \Rightarrow \mathrm{IFN} \uparrow$} & Fibroblasts & Healthy & In vitro stimulation with TNFa & TNFa induced IFN $\beta$ mRNA levels & [10] \\
\hline & Macrophages & Healthy & In vitro stimulation with $\mathrm{TNFa}$ & $\begin{array}{l}\text { TNFa induced type I IFN response program through } \\
\text { IFN regulatory factor-1, leading to an IFNß-mediated } \\
\text { autocrine loop }\end{array}$ & [11] \\
\hline & Serum & Juvenile DM & $\begin{array}{l}\text { TNF-308 promotor } \\
\text { polymorphism }\end{array}$ & $\begin{array}{l}\text { Only in untreated patients: increased levels IFNa in } \\
\text { carriers of minor allele, which is associated with } \\
\text { increased TNFa production }\end{array}$ & [43] \\
\hline & PBMCs & RRMS & $\begin{array}{l}\text { Concanavalin A-stimulated } \\
\text { PBMCs obtained from IFN } \beta \text { - } \\
\text { treated MS patients }\end{array}$ & $\begin{array}{l}\text { More production of TNFa in concanavalin A- } \\
\text { stimulated PBMCs after IFN } \beta \text { treatment }\end{array}$ & [57] \\
\hline & Monocytes & Healthy & $\begin{array}{l}\text { Pre-incubation ( } 30 \mathrm{~min}) \text { with } \\
\text { IFN } \beta \text {, subsequent stimulation } \\
\text { with LPS }\end{array}$ & $\begin{array}{l}\text { IFN } \beta \text { pretreatment enhanced LPS-induced TNFa } \\
\text { production by monocytes }\end{array}$ & [17] \\
\hline \multirow[t]{8}{*}{$\mathrm{IFN} \uparrow \Rightarrow \mathrm{TNF} \downarrow$} & Macrophages & Healthy & $\begin{array}{l}\text { In vitro pretreatment with IFNa } \\
(100 \mathrm{U} / \mathrm{ml}) \text { and subsequent } \\
\text { immune complexes, Fc receptor } \\
\text { or TLR stimulation }\end{array}$ & $\begin{array}{l}\text { IFNa suppressed FcyR-induced, TLR2-induced } \\
\text { and TLR4-induced TNFa production through } \\
\text { induction of Axl, a repressor of TNFa promoter }\end{array}$ & [15] \\
\hline & PBMCs & RRMS & $\begin{array}{l}\text { Anti-CD3-stimulated PBMCs } \\
\text { obtained from IFNß-treated MS } \\
\text { patients }\end{array}$ & $\begin{array}{l}\text { IFN } \beta \text { therapy decreased the production of TNFa } \\
\text { by anti-CD3-stimulated PBMCs }\end{array}$ & [57] \\
\hline & Synovial tissue & RA & $\begin{array}{l}\text { Type I IFN treatment of RA } \\
\text { patients }\end{array}$ & $\begin{array}{l}\text { Decreased levels of TNFa in synovial tissue in some } \\
\text { patients }\end{array}$ & [58] \\
\hline & PBMCs & Healthy & PHA and IFN $\beta$-treated PBMCs & $\begin{array}{l}\text { IFN } \beta \text { decreased PHA-induced TNFa production } \\
\text { by PBMC }\end{array}$ & [12] \\
\hline & $\begin{array}{l}\text { Co-cultures of } \\
\text { Tlymphocytes } \\
\text { and monocytes }\end{array}$ & Healthy & $\begin{array}{l}\text { Co-cultures of T lymphocytes and } \\
\text { monocytes stimulated by PHA in } \\
\text { the presence of IFN } \beta\end{array}$ & $\begin{array}{l}\text { IFNß inhibits the ability of stimulated T lymphocytes } \\
\text { to induce cell contact-mediated TNFa production } \\
\text { in monocytes }\end{array}$ & [13] \\
\hline & THP-1 & Cell line & $\begin{array}{l}\text { Pre-incubation ( } 24 \text { hours) with } \\
\text { IFN } \beta 1 \text { b, subsequent stimulation } \\
\text { with LPS in the presence or } \\
\text { absence of dexamethasone }\end{array}$ & $\begin{array}{l}\text { LPS-induced TNFa production by THP-1 cells } \\
\text { was suppressed by dexamethasone. This } \\
\text { suppressive effect was augmented by pre-incubation } \\
\text { with IFN } \beta\end{array}$ & [14] \\
\hline & Monocytes & Healthy & $\begin{array}{l}\text { Pre-incubation ( } 30 \text { min) with } \\
\text { IFNB, subsequent stimulation with } \\
\text { plasma membranes of PHA + } \\
\text { PMA-stimulated HUT- } 78 \text { cells }\end{array}$ & $\begin{array}{l}\text { Pretreatment with IFN } \beta \text { decreased TNFa } \\
\text { production by contact-activated monocytes }\end{array}$ & [17] \\
\hline & PBMCs & Healthy & $\begin{array}{l}\text { IFN } \beta \text { administration and ex vivo } \\
\text { mitogen stimulation of PBMCs }\end{array}$ & $\begin{array}{l}\text { IFN } \beta \text { induced a transient decrease of inflammatory } \\
\text { cytokines including TNFa }\end{array}$ & [56] \\
\hline $\mathrm{IFN} \downarrow \Rightarrow \mathrm{TNF} \downarrow$ & $\begin{array}{l}\text { Blood and skin } \\
\text { lesions }\end{array}$ & SLE & $\begin{array}{l}\text { Treatment with an anti-IFNa } \\
\text { antibody in SLE patients }\end{array}$ & Downmodulation of TNFa mRNA levels & [59] \\
\hline
\end{tabular}


Table 2. Complex relation between TNF and type I IFN in murine studies

\begin{tabular}{|c|c|c|c|c|c|}
\hline $\begin{array}{l}\text { Cross- } \\
\text { regulation }\end{array}$ & $\begin{array}{l}\text { Cell } \\
\text { type }\end{array}$ & $\begin{array}{l}\text { Activation } \\
\text { state }\end{array}$ & $\begin{array}{l}\text { Experimental } \\
\text { model }\end{array}$ & Results & Reference \\
\hline \multirow[t]{3}{*}{$\overline{\mathrm{IFN}} \uparrow \Rightarrow \mathrm{TNF} \downarrow$} & $\begin{array}{l}\text { Embryonic fibroblasts } \\
\text { (MEF) and } \\
\text { macrophages }\end{array}$ & $\begin{array}{l}\text { p38 MAPK } \\
\text { stimulus }\end{array}$ & $\begin{array}{l}\text { In vitro stimulation with IFN } \beta \text { and } \\
\text { p38 MAPK stimulus simultaneously }\end{array}$ & $\begin{array}{l}\text { In the presence of a p38 MAPK } \\
\text { stimulus, IFN } \beta \text { induces - via STAT1 } \\
\text { activation - TTP, which destabilizes } \\
\text { mRNA of several proinflammatory } \\
\text { genes including TNFa }\end{array}$ & [16] \\
\hline & Macrophages & IFNY and LPS & $\begin{array}{l}\text { Priming by IFNY, stimulation by } \\
\text { LPS in the presence of IFN } \beta \text {-EF } \\
\text { supernatant }\end{array}$ & $\begin{array}{l}\text { IFN } \beta \text { suppressed LPS/IFNy induced } \\
\text { TNFa production }\end{array}$ & [26] \\
\hline & Synovial tissue & $\mathrm{CIA}$ & $\begin{array}{l}\text { Daily treatment of CIA using } \\
\text { recombinant IFN } \beta \text { injection (7 days) }\end{array}$ & $\begin{array}{l}\text { FN } \beta \text { treatment reduced TNFa } \\
\text { production in the synovial tissue }\end{array}$ & {$[28]$} \\
\hline $\mathrm{IFN} \uparrow \Rightarrow \mathrm{TNF} \uparrow$ & Macrophages & Healthy & In vitro stimulation with IFN $\beta$ & IFN $\beta$ mediated upregulation of TNF mRNA & A [18] \\
\hline \multirow[t]{3}{*}{$\mathrm{IFN} \downarrow \Rightarrow \mathrm{TNF} \uparrow$} & Macrophages & LPS and IFNY & EAE in IFNß KO mice & $\begin{array}{l}\text { Increased TNFa production compared } \\
\text { with wild-type controls }\end{array}$ & [23] \\
\hline & $\begin{array}{l}\text { Spleen-derived } \\
\text { macrophages }\end{array}$ & LPS and IFNY & $\begin{array}{l}\text { Cells isolated from IFN } \beta \text {-deficient } \\
\text { mice. Priming by IFN } \text { with } \\
\text { subsequent stimulation with LPS }\end{array}$ & $\begin{array}{l}\text { Increased TNFa production compared } \\
\text { with control mice }\end{array}$ & [24] \\
\hline & Synovial tissue & $\mathrm{CIA}$ & CIA in IFN $\beta$-deficient mice & $\begin{array}{l}\text { Increased TNFa production in synovia } \\
\text { of arthritic IFN } \beta \text {-deficient mice }\end{array}$ & [24] \\
\hline $\mathrm{IFN} \downarrow \Rightarrow \mathrm{TNF} \downarrow$ & Liver & $\begin{array}{l}\text { TNFa-induced } \\
\text { lethal shock }\end{array}$ & IFNAR1 or IFN $\beta$ KO mice & $\begin{array}{l}\text { Lack of type I IFN signaling protects } \\
\text { against TNFa-induced inflammation }\end{array}$ & [25] \\
\hline $\mathrm{TNF} \downarrow \Rightarrow I F N \uparrow$ & Serum & Poly l:C & $\begin{array}{l}\text { NZB/W mouse (defect in TNF) } \\
\text { injected with poly l:C }\end{array}$ & $\begin{array}{l}\text { NZB/W mice produce more poly I:C- } \\
\text { induced IFNa }\end{array}$ & {$[22]$} \\
\hline
\end{tabular}

$\mathrm{CIA}$, collagen-induced arthritis; EAE, experimental autoimmune encephalomyelitis; EF, expressing fibroblasts; LPS, lipopolysaccharide; MAPK, mitogen-activated protein kinase; MEF, muse embryonic fibroblast; poly I:C, polyinosinic-polycytidylic acid; STAT, signal transducers and activators of transcription; TTP, tristetraprolin.

production in the effector phase of the disease [23]. Macrophages isolated from these mice after experimental autoimmune encephalomyelitis induction produced increased amounts of TNF $\alpha$ after stimulation with LPS and IFN $\gamma$, compared with wild-type controls [23]. In addition, these IFN $\beta$ KO mice are also more susceptible to collagen-induced arthritis and develop an exacerbated disease compared with control mice, with a greater production of TNF $\alpha$ [24]. Of interest, mice lacking the receptor for type I IFN (IFNAR1) or IFN $\beta$ are protected against TNF $\alpha$-induced lethal shock [25] - showing that the absence of type I IFN signaling may not only impact TNF $\alpha$ production, but also the outcome of the TNF $\alpha-$ induced inflammation.

These observations also raise the reverse question: does increased type I IFN signaling downregulate TNF $\alpha$ production and/or TNF-induced inflammation? IFN $\beta$ treatment has a significant therapeutic effect in collageninduced arthritis in mice and rhesus monkeys as well as in adjuvant arthritis in rats [26-28]. In these models, IFN $\beta$ was shown to have an inhibitory effect on the production of TNF $\alpha$ by LPS-stimulated macrophages [26]. Indirect upregulation of type I IFN also showed beneficial effects in mouse models of arthritis $[29,30]$. In addition, mice treated with IFN $\beta$ had a $50 \%$ lowered expression of TNF $\alpha$ in the synovial tissue [28].

Taken together, these animal models demonstrate the presence and functionality of the cross-regulation between TNF $\alpha$ and type I IFN, but also indicate that this cross-regulation occurs mainly in a context-dependent manner during inflammatory conditions (Table 2). These observations in turn raise the question of whether and to what extent the inflammatory conditions seen in these experimental models are relevant for human IMIDs.

\section{Cross-regulation of TNFa and type I IFN in immune- mediated inflammatory diseases}

Upregulation of type I IFN-response genes has now been observed in peripheral blood cells and/or target tissue in many different IMIDs - for example, RA [31], SLE [32], systemic scleroderma [33], multiple sclerosis (MS) [34,35], psoriasis [36,37], Sjögren's syndrome (SS) [38], dermatomyositis [39] and type 1 diabetes [40]. These findings suggest that an activated type I IFN gene expression program may be a common denominator in chronic inflammatory diseases in general. If crossregulation is present and effective, this activated type I IFN response program should lead to a repressed TNF $\alpha$ profile. Most of these diseases, however, also have an elevated expression of TNF $\alpha$ both systemically and locally in the target tissues. For example, upregulation of both TNF $\alpha$ and type I IFN has been shown in lesional skin in psoriasis [37] as well as in synovial tissues of RA [41] and juvenile idiopathic arthritis patients [42]. The question therefore arises of whether cross-regulation might be insufficient in specific pathological conditions. 
The relative balance between IFN $\alpha$ and TNF $\alpha$ has been studied in more detail in juvenile dermatomyositis. By measuring serum IFN $\alpha$ activity, higher serum IFN $\alpha$ levels were shown to be associated with the presence of the TNF $\alpha-308$ promotor polymorphism [43]. This polymorphism leads to increased production of TNF $\alpha$ in 50\% of the carriers of the minor allele [44]. In early untreated patients, serum IFN $\alpha$ activity and TNF $\alpha$ are positively correlated. As the disease progresses, however, serum IFN $\alpha$ activity levels go down while TNF $\alpha$ levels remain stable [43]. This observation indicates that type I IFN might be more important in the earliest phases of the autoimmune phase of disease, while TNF plays a more prominent role in the secondary effector phase of the disease (Figure 1b). Collectively, the relationship between both cytokines is influenced by timing and disease progression.

The relationship between type I IFN and TNF $\alpha$ also appears to be complex in SLE. Patients with SLE display a strong type I IFN signature but also systemic overexpression of TNF $\alpha$. Moreover, serum TNF $\alpha$ levels correlate with disease activity [45]. Recently, serum levels of both TNF $\alpha$ and IFN $\alpha$ were measured by ELISA in 171 SLE patients. The patients showed elevated levels of both cytokines, and the correlation between both was highly significant [46]. Another study, however, indicated that clustering of SLE patients according to serum IFN $\alpha$ activity and TNF $\alpha$ levels resulted in three groups: a group in which IFN $\alpha$ levels were much higher than TNF $\alpha$ levels, a group in which IFN $\alpha$ and TNF $\alpha$ levels were correlated, and a group in which TNF $\alpha$ levels were much higher than IFN $\alpha$ levels [47]. The latter group had a weaker association with PTPN22 SNPs than the former two groups. This study suggests that the relative balance between both cytokines may also be heterogeneous within one single disease.

This heterogeneity was also confirmed in MS, where a subgroup of patients displayed increased expression levels of type I IFN response genes in the peripheral blood [34]. The extent of this type I IFN signature before treatment was inversely associated with the biological and clinical response to IFN $\beta$ treatment $[35,48]$. Elevated TNF $\alpha$ levels have been detected in the peripheral blood and brain lesions of MS patients, and correlated with disease activity [49], but it remains unknown whether there is a relationship with the type I IFN signature.

In $\mathrm{RA}, \mathrm{TNF} \alpha$ is overexpressed in the primary target tissue of the disease - the synovial membrane [50]. In addition, the expression of IFN $\beta$ as well as the number of IFN $\alpha$-expressing and IFN $\beta$-expressing $\mathrm{pDC}$ is significantly elevated in RA synovial tissue compared with synovial tissues from patients with osteoarthritis or reactive arthritis [41]. A similar picture emerges from peripheral blood, as about one-half of the RA patient population shows elevated expression levels of type I IFN response genes compared with healthy controls [31]. In the other half of the patients, the type I IFN response gene expression profile is similar to that of healthy controls. Of interest, the peripheral blood IFN gene signature can already be observed in the preclinical phase of the disease [51]. The clinical significance of this elevated type I IFN expression profile in blood is still unknown, as there is no difference in patient characteristics or disease severity between patients with elevated or normal expression levels of type I IFN response genes. Thus, in RA both cytokines appear to be elevated systemically as well as in the target tissue.

Together, these studies in different IMIDs clearly indicate that there is no straightforward balance between the levels of type I IFN and TNF $\alpha$, and that factors such as the specific type of IMID, the disease phase, and patient-specific factors may contribute to create a complex picture. One also has to consider that it is not completely clear how the absolute levels of these cytokines relate to their functional activity and role in disease pathogenesis.

\section{Cross-regulation of TNFa and type I IFN during targeted treatment}

Targeted therapies aimed at regulating cytokine activity provide an experimental approach to study crossregulation between $\mathrm{TNF} \alpha$ and type I IFN in patients. In fact, the concept of TNF $\alpha$ /type I IFN cross-regulation proposed by Banchereau and colleagues was based on the observation that juvenile chronic arthritis patients treated with infliximab (anti-TNF $\alpha$ monoclonal antibody) displayed increased transcription of IFN $\alpha$-regulated genes compared with untreated patients. However, the inter-individual variability in the expression of IFN $\alpha$, the relative small number of patients, and the cross-sectional design warranted further translational confirmation of these findings in prospective studies.

Studying 33 RA patients during treatment with infliximab, we observed no overall modulation of the expression of type I IFN response genes by TNF $\alpha$ blockade. Further analysis, however, revealed that infliximab induced an upregulation of the type I IFN genes in a subset of patients with a poor clinical response to treatment [52]. In contrast, the type I IFN response genes were not affected in patients with a good response to TNF $\alpha$ blockade. In spondyloarthritis, a disease that responds very well to TNF $\alpha$ blockade, infliximab treatment induced a small decrease of type I IFN serum activity after 2 weeks but the levels returned to baseline after 12 weeks of treatment. TNF $\alpha$ blockade with the soluble TNF $\alpha$ receptor etanercept led to a small increase in type I IFN serum activity after 12 weeks of treatment in a comparable patient population [53]. Similar results 
have been reported for patients with SS and inflammatory myopathies. In SS patients, treatment with the soluble TNF $\alpha$ receptor construct etanercept, which is not clinically effective in SS [54], increased serum IFN $\alpha$ activity [9]. In patients with inflammatory myopathies, infliximab induced an increase in type I IFN serum activity without any clinical improvement and even disease exacerbation in some patients [55]. Collectively, these longitudinal studies indicate that the effect of TNF $\alpha$ blockade on type I IFN is not universal and may depend on the disease, the type of TNF $\alpha$ blocker, as well as the clinical response to treatment.

How are TNF $\alpha$ levels and/or activity affected by type I IFN treatment? In healthy volunteers, administration of IFN $\beta$ induced a transient decrease of the production of TNF $\alpha$ as well as other inflammatory cytokines such as IL$1 \beta$, IL-6 and lymphotoxin by PBMCs upon ex vivo stimulation [56]. In MS, IFN $\beta$ treatment was also associated with decreased production of TNF $\alpha$ by anti-CD3stimulated PBMCs. In contrast, concanavalin A-stimulated PBMCs produced more TNF $\alpha$ after IFN $\beta$ treatment [57], indicating again that the proposed cross-regulation is not universal but is dependent on factors such as stimulus and cell type. In a proof-of-concept trial in RA patients [27], type I IFN treatment had an immunomodulatory effect on synovial tissue inflammation with decreased levels of synovial TNF $\alpha$ expression in some but not all patients [58]. Conversely, treatment with an anti-IFN $\alpha$ monoclonal antibody downmodulated TNF $\alpha$ mRNA expression in peripheral blood and skin lesions in SLE patients [59]. Before treatment TNFa levels were increased compared with healthy controls, but the levels returned to normal 1 day after anti-IFN $\alpha$ treatment. These data indicate that administration of type I IFN $\beta$ may lead to suppression of TNF $\alpha$ production in RA, whereas blocking IFN $\alpha$ does not directly entail elevation of TNF $\alpha$ levels. Consistent with preclinical studies, this experience with targeted interventions in patients highlights the dependence of the interaction between TNF $\alpha$ and type I IFN on the specific type I IFN subtype, the pathogenesis of the disease, and the intrinsic characteristics of the patient.

\section{Clinical relevance of proposed cross-regulation between type I IFN and TNFa}

The cellular, experimental, and human data reviewed here indicate that cross-regulation between type I IFN and TNF $\alpha$ may occur in homeostatic conditions but is certainly not a universal principle in IMIDs. The presence or absence of the cross-regulation seems to depend on many factors, including the exact cell type, the type and level of activation, the specific IMID and, within a single IMID, the individual patient. This complexity questions the potential clinical implications of the conceptual framework of type I IFN-TNF $\alpha$ cross-regulation. Three relevant questions in this context are as follows: Can the type I IFN signature in IMID contribute to prediction of response to TNF $\alpha$ blockade? Can successful TNF $\alpha$ blockade induce type I IFN-driven adverse effects? And would IFN treatment be a viable option in TNF-driven IMIDs?

Since not all IMID patients respond well to anti-TNFa therapy, it is very relevant to identify biomarkers predicting clinical efficacy. Could the type I IFN signature be such a biomarker contributing to the prediction of response? The expression of type I IFN response genes are upregulated after TNF blockade, especially in patients who have a poor clinical response to treatment $[9,52]$. In patients with a good response to treatment, the expression of type I IFN response genes seems unaffected by TNF $\alpha$ blockade.

If the regulation of type I IFN is impeded by successful TNF $\alpha$ blockade, does this subsequently lead to type I IFN-driven adverse events? Type I IFN is known to play an important role in B-cell activation and plasma cell differentiation, and the levels are associated with the presence of autoantibodies in SLE [60]. Accordingly, it is conceivable that modulation of type I IFN by TNF blockade may have an impact on autoantibodies. In RA patients, however, TNF blockade had similar effects on the levels of circulating autoantibodies such as rheumatoid factor or anti-citrullinated protein antibodies in type I IFN ${ }^{\text {high }}$ patients and type I IFN low patients [61]. Moreover, the induction of anti-nuclear antibodies by TNF blockade, a phenomenon that is frequently observed in both RA and spondyloarthritis [62], was not related to changes in the serum type I IFN activity [53]. From this we can conclude that there is no influence of the interplay between TNF $\alpha$ and type I IFN with respect to autoantibody production during TNF blockade.

Another intriguing side effect of TNF blockade is the induction of psoriasis-like disease in 3 to $5 \%$ of arthritis patients without pre-existing psoriasis, which was completely unexpected considering the excellent clinical response of psoriasis to TNF blockade [63]. This side effect was hypothesized to be due to the proposed crossregulation between TNF $\alpha$ and type I IFN. Recent studies of human psoriatic tissue demonstrate that IFN $\alpha$ is present early in the disease process but is not detectable in the stable plaque, although downstream IFN $\alpha$ signaling continues to be upregulated. [64]. Indeed, skin biopsies of four patients with anti-TNFa-induced psoriasis displayed increased expression of myxovirusresistance protein A (a protein specifically induced by type I IFN) compared with biopsies from patients with psoriasis vulgaris [65]. It would be of interest to extend this cohort and analyze in more detail the type I IFN profile to provide formal evidence for the hypothesis that TNF $\alpha$ blockade can induce or enhance type I IFN, and thereby psoriasis, in these patients. 
A third clinically relevant question based on the potential cross-regulation is whether type I IFN treatment could be a successful treatment strategy in TNF-driven IMIDs. In animal models for arthritis, a beneficial effect of IFN $\beta$ treatment on both swelling and joint destruction has consistently been observed $[26,28]$. Similar results have been obtained in a collagen-induced arthritis model in rhesus monkeys [27]. A multicenter, randomized, double-blind, placebo-controlled phase II study of subcutaneous IFN $\beta 1 \mathrm{a}$ in 209 patients with active RA, however, did not indicate a clinical or radiological effect [66]. This discrepancy might relate to the mode of administration and the difference in IFN $\beta 1$ a dosages used in man and mice. A successful example of IFN $\beta$ treatment is observed in MS, a disease in which TNFo has been shown to play an important role [49]. Further investigation of type I IFN therapy using innovative approaches is thus warranted in RA and other TNFdriven IMIDs.

\section{Conclusion}

The present review summarizes the currently available clinical evidence for the proposed cross-regulation between TNF $\alpha$ and type I IFN at the cellular level as well as in vivo in experimental models and in patients with IMIDs (Tables 1 and 2). Since both cytokines have pleiotropic effects that depend on the timing, dosage and cell type, the in vitro studies yielded conflicting results and indicated that the proposed cross-regulation is not as clear cut as anticipated. Moreover, the molecular mechanism of cross-regulation between both cytokines is completely unclear and might be an indirect result through the induction of other factors. Most experimental in vivo models support the concept of crossregulation between both cytokines but again some studies yielded opposite results, confirming the fact that the cross-regulation may be context dependent.

The studies in patients with different IMIDs show there is not necessarily a direct balance between the levels of type I IFN and TNF $\alpha$, and that factors such as the type of IMID, the disease phase, and patient heterogeneity may contribute to create a complex picture. It is also possible in patients with IMIDs that both cytokines are elevated and are still influencing each other's levels from rising even further.

An additional layer of complexity is added by the subtle differences in function of the different subtypes of type I IFN and the difficulty to directly measure these individual isoforms. The usage of type I IFN-induced genes is valuable, but this signature is not always a synonym for the presence of type I IFN specifically. Moreover, how the levels of these cytokines relate to their functional activity and role in disease pathogenesis is still to be investigated.

\section{Abbreviations}

ELISA, enzyme-linked immunosorbent assay; IFN, interferon; IL, interleukin; IMID, immune-mediated inflammatory disease; LPS, lipopolysaccharide; MS, multiple sclerosis; NF, nuclear factor; PBMC, peripheral blood mononuclear cell; pDC, plasmacytoid dendritic cells; RA, rheumatoid arthritis; SLE, systemic lupus erythematosus; SNP, single nucleotide polymorphism; SS, Sjögren's syndrome; Th, T-helper type; TNF, tumor necrosis factor

\section{Competing interests}

TC, DB and LGMvB have no competing interests. PPT is Chief Scientific Officer of Arthrogen and holds shares in Arthrogen b.v. PPT is owner of the following patent: Method for prognosticating the clinical response of a patient to B-lymphocyte inhibiting or depelting therapy.

\section{Published: 28 October 2010}

\section{References}

1. Gogas H, loannovich J, Dafni U, Stavropoulou-Giokas C, Frangia K, Tsoutsos D, Panagiotou P, Polyzos A, Papadopoulos O, Stratigos A, Markopoulos C, Bafaloukos D, Pectasides D, Fountzilas G, Kirkwood JM: Prognostic significance of autoimmunity during treatment of melanoma with interferon. N Engl J Med 2006, 354:709-718.

2. Zhuang H, Kosboth M, Lee P, Rice A, Driscoll DJ, Zori R, Narain S, Lyons R, Satoh M, Sobel E, Reeves WH: Lupus-like disease and high interferon levels corresponding to trisomy of the type I interferon cluster on chromosome 9p. Arthritis Rheum 2006, 54:1573-1579.

3. Tak PP, Firestein GS: NF-KB: a key role in inflammatory diseases. $J$ Clin Invest 2001, 107:7-11.

4. Tracey D, Klareskog L, Sasso EH, Salfeld JG, Tak PP: Tumor necrosis factor antagonist mechanisms of action: a comprehensive review. Pharmacol Ther 2008, 117:244-279

5. Armaka M, Apostolaki M, Jacques P, Kontoyiannis DL, Elewaut D, Kollias G: Mesenchymal cell targeting by TNF as a common pathogenic principle in chronic inflammatory joint and intestinal diseases. J Exp Med 2008, 205:331-337.

6. Banchereau J, Pascual V: Type I interferon in systemic lupus erythematosus and other autoimmune diseases. Immunity 2006, 25:383-392.

7. Ivashkiv LB: Type I interferon modulation of cellular responses to cytokines and infectious pathogens: potential role in SLE pathogenesis. Autoimmunity 2003, 36:473-479.

8. Palucka AK, Blanck JP, Bennett L, Pascual V, Banchereau J: Cross-regulation of TNF and IFN-a in autoimmune diseases. Proc Natl Acad Sci U S A 2005, 102:3372-3377.

9. Mavragani CP, Niewold TB, Moutsopoulos NM, Pillemer SR, Wahl SM, Crow MK: Augmented interferon-alpha pathway activation in patients with Sjogren's syndrome treated with etanercept. Arthritis Rheum 2007, 56:3995-4004

10. Reis $L F, H o L T$, Vilcek J: Tumor necrosis factor acts synergistically with autocrine interferon-beta and increases interferon-beta mRNA levels in human fibroblasts. J Biol Chem 1989, 264:16351-16354.

11. Yarilina A, Park-Min KH, Antoniv T, Hu X, Ivashkiv LB: TNF activates an IRF1dependent autocrine loop leading to sustained expression of chemokines and STAT1-dependent type I interferon-response genes. Nat Immunol 2008, 9:378-387.

12. Coclet-Ninin J, Dayer JM, Burger D: Interferon-beta not only inhibits interleukin- $1 \beta$ and tumor necrosis factor-alpha but stimulates interleukin-1 receptor antagonist production in human peripheral blood mononuclear cells. Eur Cytokine Netw 1997, 8:345-349.

13. Jungo F, Dayer JM, Modoux C, Hyka N, Burger D: IFN- $\beta$ inhibits the ability of T lymphocytes to induce TNF- $\alpha$ and IL-1 $\beta$ production in monocytes upon direct cell-cell contact. Cytokine 2001, 14:272-282.

14. Uitdehaag BM, Hoekstra K, Koper JW, Polman CH, Dijkstra CD: IFN- $\beta 1$ b augments glucocorticoid-induced suppression of tumor necrosis factoralpha production by increasing the number of glucocorticoid receptors on a human monocytic cell line. J Interferon Cytokine Res 2001, 21:133-135.

15. Sharif MN, Sosic D, Rothlin CV, Kelly E, Lemke G, Olson EN, Ivashkiv LB: Twist mediates suppression of inflammation by type I IFNs and Axl. J Exp Med 2006, 203:1891-1901

16. Sauer I, Schaljo B, Vogl C, Gattermeier I, Kolbe T, Muller M, Blackshear PJ, Kovarik P: Interferons limit inflammatory responses by induction of tristetraprolin. Blood 2006, 107:4790-4797. 
17. Molnarfi N, Gruaz L, Dayer JM, Burger D: Opposite effects of IFN beta on cytokine homeostasis in LPS- and T cell contact-activated human monocytes. J Neuroimmunol 2004, 146:76-83.

18. O'Connell RM, Taganov KD, Boldin MP, Cheng G, Baltimore D: MicroRNA-155 is induced during the macrophage inflammatory response. Proc Natl Acad SciUS A 2007, 104:1604-1609.

19. Taniguchi T, Takaoka A: A weak signal for strong responses: interferonalpha/beta revisited. Nat Rev Mol Cell Biol 2001, 2:378-386.

20. Jacob CO, McDevitt HO: Tumour necrosis factor-alpha in murine autoimmune'lupus' nephritis. Nature 1988, 331:356-358.

21. Lu Q, Shen N, Li XM, Chen SL: Genomic view of IFN-a response in preautoimmune NZB/W and MRL/Ipr mice. Genes Immun 2007, 8:590-603

22. Santiago-Raber ML, Baccala R, Haraldsson KM, Choubey D, Stewart TA, Kono DH, Theofilopoulos AN: Type-l interferon receptor deficiency reduces lupus-like disease in NZB mice. J Exp Med 2003, 197:777-788.

23. Teige I, Treschow A, Teige A, Mattsson R, Navikas V, Leanderson T, Holmdahl R, Issazadeh-Navikas S: IFN- $\beta$ gene deletion leads to augmented and chronic demyelinating experimental autoimmune encephalomyelitis. I Immunol 2003, 170:4776-4784.

24. Treschow AP, Teige I, Nandakumar KS, Holmdahl R, Issazadeh-Navikas S: Stromal cells and osteoclasts are responsible for exacerbated collageninduced arthritis in interferon-beta-deficient mice. Arthritis Rheum 2005, 52:3739-3748

25. Huys L, Van HF, Dejager L, Dejonckheere E, Lienenklaus S, Weiss S, Leclercq G, Libert C: Type I interferon drives tumor necrosis factor-induced lethal shock. J Exp Med 2009, 206:1873-1882.

26. Triantaphyllopoulos KA, Williams RO, Tailor H, Chernajovsky Y: Amelioration of collagen-induced arthritis and suppression of interferon-gamma, interleukin-12, and tumor necrosis factor alpha production by interferonbeta gene therapy. Arthritis Rheum 1999, 42:90-99.

27. Tak PP, Hart BA, Kraan MC, Jonker M, Smeets TJ, Breedveld FC: The effects of interferon beta treatment on arthritis. Rheumatology (Oxford) 1999, 38:362-369.

28. van Holten J., Reedquist K, Sattonet-Roche P, Smeets TJ, Plater-Zyberk C, Vervoordeldonk MJ, Tak PP: Treatment with recombinant interferon-beta reduces inflammation and slows cartilage destruction in the collageninduced arthritis model of rheumatoid arthritis. Arthritis Res Ther 2004, 6:R239-R249.

29. Corr M, Boyle DL, Ronacher L, Flores N, Firestein GS: Synergistic benefit in inflammatory arthritis by targeting IKB kinase epsilon and interferon beta. Ann Rheum Dis 2009, 68:257-263.

30. Yarilina A, DiCarlo E, Ivashkiv LB: Suppression of the effector phase of inflammatory arthritis by double-stranded RNA is mediated by type I IFNs. J Immunol 2007, 178:2204-2211.

31. van der Pouw Kraan TC, Wijbrandts CA, van Baarsen LG, Voskuyl AE, Rustenburg F, Baggen JM, Ibrahim SM, Fero M, Dijkmans BA, Tak PP, Verweij $\mathrm{CL}$ : Rheumatoid arthritis subtypes identified by genomic profiling of peripheral blood cells: assignment of a type I interferon signature in a subpopulation of patients. Ann Rheum Dis 2007, 66:1008-1014.

32. Bennett $L$, Palucka AK, Arce E, Cantrell V, Borvak J, Banchereau J, Pascual V: Interferon and granulopoiesis signatures in systemic lupus erythematosus blood. J Exp Med 2003, 197:711-723.

33. Tan FK, Zhou X, Mayes MD, Gourh P, Guo X, Marcum C, Jin L, Arnett FC, Jr: Signatures of differentially regulated interferon gene expression and vasculotrophism in the peripheral blood cells of systemic sclerosis patients. Rheumatology (Oxford) 2006, 45:694-702.

34. van Baarsen LG, van der Pouw Kraan TC, Kragt JJ, Baggen JM, Rustenburg F, Hooper T, Meilof JF, Fero MJ, Dijkstra CD, Polman CH, Verweij CL: A subtype of multiple sclerosis defined by an activated immune defense program. Genes Immun 2006, 7:522-531.

35. Comabella M, Lunemann JD, Rio J, Sanchez A, Lopez C, Julia E, Fernandez M, Nonell L, Camina-Tato M, Deisenhammer F, Caballero E, Tortola MT, Prinz M, Montalban X, Martin R: A type I interferon signature in monocytes is associated with poor response to interferon-beta in multiple sclerosis. Brain 2009, 132:3353-3365.

36. van der FL, van der Wel LI, Laman JD, Prens EP, Verschuren MC: In psoriasis lesional skin the type I interferon signaling pathway is activated, whereas interferon-al pha sensitivity is unaltered. J Invest Dermatol 2004, 122:51-60.

37. Yao Y, Richman L, Morehouse C, de los RM, Higgs BW, Boutrin A, White B, Coyle A, Krueger J, Kiener PA, Jallal B: Type I interferon: potential therapeutic target for psoriasis? PLoS One 2008, 3:e2737.
38. Bave U, Nordmark G, Lovgren T, Ronnelid J, Cajander S, Eloranta ML, Alm GV, Ronnblom L: Activation of the type I interferon system in primary Sjogren's syndrome: a possible etiopathogenic mechanism. Arthritis Rheum 2005, 52:1185-1195.

39. Greenberg SA, Pinkus JL, Pinkus GS, Burleson T, Sanoudou D, Tawil R, Barohn RJ, Saperstein DS, Briemberg HR, Ericsson M, Park P, Amato AA: Interferonalpha/beta-mediated innate immune mechanisms in dermatomyositis. Ann Neurol 2005, 57:664-678.

40. Huang X, Yuang J, Goddard A, Foulis A, James RF, Lernmark A, Pujol-Borrell R, Rabinovitch A, Somoza N, Stewart TA: Interferon expression in the pancreases of patients with type I diabetes. Diabetes 1995, 44:658-664

41. van Holten J, Smeets TJ, Blankert P, Tak PP: Expression of interferon beta in synovial tissue from patients with rheumatoid arthritis: comparison with patients with osteoarthritis and reactive arthritis. Ann Rheum Dis 2005, 64:1780-1782.

42. Gattorno M, Chicha L, Gregorio A, Ferlito F, Rossi F, Jarrossay D, Lanzavecchia A, Martini A, Manz MG: Distinct expression pattern of IFN- $a$ and TNF- $a$ in juvenile idiopathic arthritis synovial tissue. Rheumatology (Oxford) 2007, 46:657-665.

43. Niewold TB, Kariuki SN, Morgan GA, Shrestha S, Pachman LM: Elevated serum interferon-alpha activity in juvenile dermatomyositis: associations with disease activity at diagnosis and after thirty-six months of therapy. Arthritis Rheum 2009, 60:1815-1824.

44. Pachman LM, Liotta-Davis MR, Hong DK, Kinsella TR, Mendez EP, Kinder JM, Chen EH: TNFa-308A allele in juvenile dermatomyositis: association with increased production of tumor necrosis factor alpha, disease duration, and pathologic calcifications. Arthritis Rheum 2000, 43:2368-2377.

45. Studnicka-Benke A, Steiner G, Petera P, Smolen JS: Tumour necrosis factor alpha and its soluble receptors parallel clinical disease and autoimmune activity in systemic lupus erythematosus. Br J Rheumatol 1996, 35:1067-1074.

46. Lopez P, Gomez J, Prado C, Gutierrez C, Suarez A: Influence of functional interleukin 10/tumor necrosis factor-alpha polymorphisms on interferonalpha, IL-10, and regulatory T cell population in patients with systemic lupus erythematosus receiving antimalarial treatment. J Rheumatol 2008, 35:1559-1566.

47. Kariuki SN, Crow MK, Niewold TB: The PTPN22 C1858T polymorphism is associated with skewing of cytokine profiles toward high interferon-alpha activity and low tumor necrosis factor alpha levels in patients with lupus. Arthritis Rheum 2008, 58:2818-2823.

48. van Baarsen LG, Vosslamber S, Tijssen M, Baggen JM, van d, V, Killestein J, van der Pouw Kraan TC, Polman CH, Verweij CL: Pharmacogenomics of interferon-beta therapy in multiple sclerosis: baseline IFN signature determines pharmacological differences between patients. PLoS One 2008, 3:e1927.

49. Rieckmann P, Albrecht M, Kitze B, Weber T, Tumani H, Broocks A, Luer W, Helwig A, Poser S: Tumor necrosis factor-alpha messenger RNA expression in patients with relapsing-remitting multiple sclerosis is associated with disease activity. Ann Neurol 1995, 37:82-88.

50. Tak PP, Smeets TJ, Daha MR, Kluin PM, Meijers KA, Brand R, Meinders AE, Breedveld FC: Analysis of the synovial cell infiltrate in early rheumatoid synovial tissue in relation to local disease activity. Arthritis Rheum 1997, 40:217-225.

51. van Baarsen $L G$, Bos WH, Rustenburg F, van der Pouw Kraan TC, Wolbink GJ, Dijkmans BA, van SD, Verweij CL: Gene expression profiling in autoantibody-positive patients with arthralgia predicts development of arthritis. Arthritis Rheum 2010, 62:694-704.

52. van Baarsen $L G$, Wijbrandts $C A$, Rustenburg F, Cantaert $T$, van der Pouw Kraan TC, Baeten DL, Dijkmans BA, Tak PP, Verweij CL: Regulation of IFN response gene activity during infliximab treatment in rheumatoid arthritis is associated with clinical response to treatment. Arthritis Res Ther 2010, 12:R11.

53. Cantaert T, De RL, Mavragani CP, Wijbrandts CA, Niewold TB, Niers T, Vandooren B, Veys EM, Richel D, Tak PP, Crow MK, Baeten D: Exposure to nuclear antigens contributes to the induction of humoral autoimmunity during tumour necrosis factor alpha blockade. Ann Rheum Dis 2009, 68:1022-1029

54. Mariette X, Ravaud P, Steinfeld S, Baron G, Goetz J, Hachulla E, Combe B, Puechal X, Pennec Y, Sauvezie B, Perdriger A, Hayem G, Janin A, Sibilia J: Inefficacy of infliximab in primary Sjogren's syndrome: results of the randomized, controlled Trial of Remicade in Primary Sjogren's Syndrome 
(TRIPSS). Arthritis Rheum 2004, 50:1270-1276.

55. Dastmalchi M, Grundtman C, Alexanderson H, Mavragani CP, Einarsdottir $\mathrm{H}$, Helmers SB, Elvin K, Crow MK, Nennesmo I, Lundberg IE: A high incidence of disease flares in an open pilot study of infliximab in patients with refractory inflammatory myopathies. Ann Rheum Dis 2008, 67:1670-1677.

56. Rothuizen LE, Buclin T, Spertini F, Trinchard I, Munafo A, Buchwalder PA, Ythier $A$, Biollaz J: Influence of interferon beta-1a dose frequency on PBMC cytokine secretion and biological effect markers. J Neuroimmunol 1999, 99:131-141.

57. Brod SA, Marshall GD, Jr, Henninger EM, Sriram S, Khan M, Wolinsky JS: Interferon-beta $1 \mathrm{~b}$ treatment decreases tumor necrosis factor-alpha and increases interleukin-6 production in multiple sclerosis. Neurology 1996 46:1633-1638

58. Smeets TJ, Dayer JM, Kraan MC, Versendaal J, Chicheportiche R, Breedveld FC, Tak PP: The effects of interferon-beta treatment of synovial inflammation and expression of metalloproteinases in patients with rheumatoid arthritis. Arthritis Rheum 2000, 43:270-274.

59. Yao Y, Richman L, Higgs BW, Morehouse CA, de los RM, Brohawn P, Zhang J, White B, Coyle AJ, Kiener PA, Jallal B: Neutralization of interferon-alpha/ beta-inducible genes and downstream effect in a phase I trial of an antiinterferon-alpha monoclonal antibody in systemic lupus erythematosus. Arthritis Rheum 2009, 60:1785-1796.

60. Kirou KA, Lee C, George S, Louca K, Peterson MG, Crow MK: Activation of the interferon-alpha pathway identifies a subgroup of systemic lupus erythematosus patients with distinct serologic features and active disease. Arthritis Rheum 2005, 52:1491-1503.

61. Cantaert T, van Baarsen LG, Wijbrandts CA, Thurlings RM, van de Sande MG, Bos C, van der Pouw TK, Verweij CL, Tak PP, Baeten DL: Type I interferons have no major influence on humoral autoimmunity in rheumatoid arthritis. Rheumatology (Oxford) 2010, 49:156-166.

62. De RL, Kruithof E, Van DN, Hoffman IE, Van den BN, Van den BF, Veys EM, De KF: Antinuclear antibodies following infliximab treatment in patients with rheumatoid arthritis or spondylarthropathy. Arthritis Rheum 2003, 48:1015-1023.

63. Cuchacovich R, Espinoza CG, Virk Z, Espinoza LR: Biologic therapy (TNF-a antagonists)-induced psoriasis: a cytokine imbalance between TNF-a and IFN-a? J Clin Rheumatol 2008, 14:353-356.

64. Nestle FO, Conrad C, Tun-Kyi A, Homey B, Gombert M, Boyman O, Burg G, Liu YJ, Gilliet M: Plasmacytoid predendritic cells initiate psoriasis through interferon-alpha production. J Exp Med 2005, 202:135-143.

65. de Gannes GC, Ghoreishi M, Pope J, Russell A, Bell D, Adams S, Shojania K, Martinka M, Dutz JP: Psoriasis and pustular dermatitis triggered by TNF-a inhibitors in patients with rheumatologic conditions. Arch Dermatol 2007, 143:223-231

66. van Holten J., Pavelka K, Vencovsky J, Stahl H, Rozman B, Genovese M, Kivitz AJ, Alvaro J, Nuki G, Furst DE, Herrero-Beaumont G, Mclnnes IB, Musikic P, Tak PP: A multicentre, randomised, double blind, placebo controlled phase II study of subcutaneous interferon beta-1a in the treatment of patients with active rheumatoid arthritis. Ann Rheum Dis 2005, 64:64-69.

doi:10.1186/ar3150

Cite this article as: Cantaert T, et al.: Type I IFN and TNFa cross-regulation in immune-mediated inflammatory disease: basic concepts and clinical relevance. Arthritis Research \& Therapy 2010, 12:219. 